\title{
Voters with Disabilities in the 2020 Regional Head Elections in Media Coverage and the Covid-19 Pandemic $^{*}$
}

\author{
Agus Machfud Fauzi ${ }^{1 *}$, Martinus Legowo ${ }^{2}$, Moh Mudzakir ${ }^{3}$, Novi \\ Fitia Maliha ${ }^{4}$, Ardhie Raditya $^{5}$ \\ 1,2,3 Universitas Negeri Surabaya \\ ${ }^{4}$ Institut Agama Islam Negeri Pononorogo \\ ${ }^{5}$ Universitas Negeri Surabaya \\ *Corresponding Author. Email: agusmfauzi@unesa.ac.id
}

\begin{abstract}
Reporting on voters with disabilities in the Pilkada is a concern because of the importance of them exercising their right to vote sometimes not in accordance with the existence of their aspirations for the future of a region. Their reporting in the range of the Covid-19 Pandemic Pilkada is relatively massive, but they are more difficult to identify the candidates for regional heads to be elected. The purpose of this study is to determine the participation of voters with disabilities in the 2020 elections. This study uses a mixed method of qualitative and quantitative based on media discourse in reporting on voters with disabilities. The theory of rationality is used to analyze the participation of disabled voters in an atmosphere of covid-19 with media coverage. The results of the reseach explain that media coverage has an effect on the participation of disabled voters even though they have not presented them at the polling station optimally. Voters' trust and distrust of regional head candidates plays a major role in the presence of disabled voters.
\end{abstract}

Keywords: disability voters, participation, covid-19.

\section{INTRODUCTION}

Voters with disabilities are one of the voters who must be considered because their right to vote has the same value and quality compared to other voters.[1] They sometimes exercise their right to vote, sometimes they don't, depending on each voter. In the 2020 Pilkada in Surabaya, voters with disabilities exercised their right to vote more than fifty processes out of the total number of disabled voters. Nationally, it was reported that there were $64.42 \%$ of disabled voters who exercised their right to vote.[2], [3]

Reporting in the Republika daily media that related to criticism of the number of disabled voters who had not been updated on the voter list by the election organizers during the Pilkada stage. This also happened in areas that held Pilkada. General Chairperson of the General Election Center for Access for Persons with Disabilities (PPUA Penca), he said, the potential number of disabled voters was 137,247 people from the total potential voters list (DP4) in the 2020 Pilkada of $105,396,460$ people, this is a criticism of data collection on disability groups who have rights. the politics of its members are not yet accurate.[4] Election organizers responded to this by commenting on facilitating voters with disabilities. Media Indonesia gave news that disabilityfriendly access was an important part of the KPU's attention to the implementation of the COVID-19 protocol in the 2020 simultaneous elections.[5] Technically, it has been arranged in such a way for the voting method for the blind, deaf, and physically disabled as shown on the online media Tirto.id. [6], [7]

The experience of voters with disabilities in their grouping can see how the experience in West Sumatra Province is divided into five groups of voters with disabilities based on the type of disability, namely: (1) physically disabled, (2) blind, (3) deaf/speaking, (4) Tuna Grahita, and (5) Other Disabilities. Election organizers attempted to use disabled voters in previous elections.[3] The research suggests that polling stations are located in places that are easily accessible, including by persons with disabilities, do not combine villages, and pay attention to 
geographical aspects and ensure that every voter can cast his vote directly, freely and confidentially.[8], [7]

The use of disability suffrage is important. Those that guarantee voters with disabilities include the Universal Declaration of Human Rights, the International Covenant on Civil and Political Rights (ICCPR), Law Number 8 of 2016 concerning Persons with Disabilities. [9] This illustrates that they should not be subordinated or ignored.

The limited number of election organizers makes voters with disabilities less likely to attend polling stations as research in Kab. Sleman. The limited number of KPU officers who have the ability to communicate in sign language for deaf and speech impaired persons causes socialization to be less than optimal. The existence of competent partners is needed by the KPU to socialize the election to persons with disabilities. [10]

The role of persons with disabilities to participate in politics can be classified into two types, namely individual roles and organizational roles. Individually, several people with disabilities in previous research in Jember Regency, have a strong motivation to be active in practical politics, both as political party cadres, legislative candidates, election management committees. These individuals actively participate in providing insight and information to persons with disabilities. Through this organization, persons with disabilities get various information about accessible elections and the importance of disability in order to participate in elections. The existence of organizations of persons with disabilities is also a mediation between the interests of potential rulers.[1]

There is no research on the participation of disabled voters during the COVID-19 pandemic. Various previous studies described the participation of disabled voters in various elections before the COVID-19 pandemic. The novelty of this research is that it was carried out during the covid-19 pandemic by producing voter participation with disabilities whose participation rates were high compared to previous elections.

\section{METHODS}

Researchers conducted research by conducting a survey first to 292 respondents. Researchers used mixed methods to examine reporting on voter participation with disabilities in the 2020 Pilkada. Researchers chose mixed methods to make it easier to conduct research by producing in-depth public understanding of voter participation with disabilities in the COVID-19 pandemic sauna, which they should not feel interested in attending TPS. because they are in a disability condition, on the other hand they are threatened by the covid-19 pandemic[11]

The mixed method is showing a quantitative method to find out the community's response to disability voter participation.[12] This is used to balance the voter turnout with disabilities. While the quantitative method is used to deepen the information of the community, so that there is a variety of in-depth information from the community, not limited to short answers that are still multi-interpreted. Media information is a good addition to this research. [13]

The researcher uses rational theory to analyze the participation of disabled voters, so that it is solved, namely why they are still eager to attend TPS to exercise their right to vote.[14] Not the other way around, they are even lazy to participate in the use of their right to vote.

\section{RESULTS AND DISCUSSION}

. Research based on information in the mass media, respondents and community information places disabled voters having a high participation in the implementation of the 2020 Pilkada in various regions. Communities who are part of the research provide quantitative responses to various existing data, as well as provide information to explore research results. [15], [16], [4], [17].

Elections are a place to bring leaders. Pilkada is part of the general election to present a leader. The participation of candidates in offering themselves to the public as potential leaders sometimes communicates that clash, so that sometimes it creates election conflicts. [18], [19], [20], [21] This also happens during the COVID19 pandemic.

People who have knowledge about voters with disabilities have various descriptions from one place to another, or from one polling station to another. The questions asked are: Are there voters with disabilities (deaf, blind, etc.) in your neighborhood in the 2020 Pilkada? (If there is no 2020 Pilkada, then the answer is based on the 2019 Election)? The answer can be seen as follows:.

People's perceptions and knowledge were answered after the face-to-face learning implementation took place. For example, at the State University of Surabaya, it is translated with the implementation of a hybrid model, namely 30 percent of students are allowed to enter if they live in Surabaya, Gresik and Sidoarjo by showing their KTP (Kartu Identity). It is a solution to different desires, expectations and perceptions. 


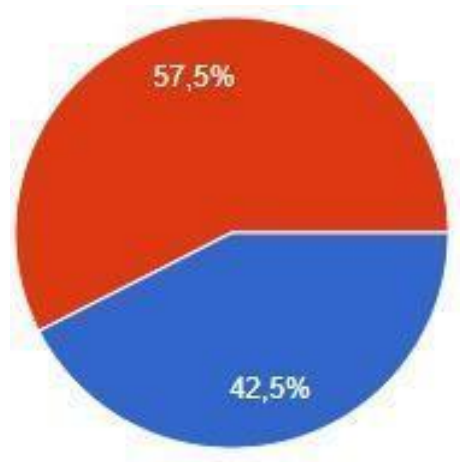

There are

There are not

Figure 1. Voter Participation

Figure shows that not all regions have disabled voters with a magnitude of $57.5 \%$. This illustrates that more regions do not know about disability voter participation. As for the area with a smaller number of disabled voters, $42.5 \%$.

Information about public knowledge about disabled voters varies. This could be due to the fact that voters with disabilities are difficult to detect. This is because some of the disabled voters stay alone, avoiding meeting with other people. Feeling insecure when meeting other people. [22]

Society in general does not yet have the same knowledge of the existence of disabled voters. This is because people in general are too busy with their personal activities, so they don't care about other neighbors. An area that has sufficient area for a village or sub-district makes a person's knowledge of voters with disabilities different. There are those who think the same about the position and position of voters with disabilities in the elections during the COVID-19 pandemic.

To deepen the participation of disabled voters, questions were asked about the participation of disabled voters with the use of their voting rights. The questions posed to respondents and informants were as follows: Are they voters with disabilities (deaf, blind, etc.) exercising their right to vote in the 2020 Pilkada? (If there is no 2020 Pilkada, then the answer is based on the 2019 Election). Their answers are described as follows:

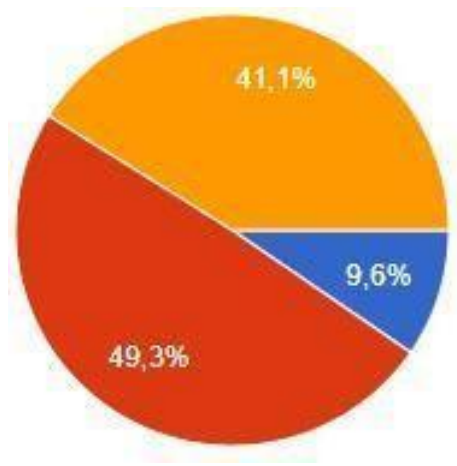

Yes, they are actively exercising their right to vote independently

Yes, they are present at TPS assisted by officers Absen at TPS

Figure 2. Present at the TPS

The figure illustrates that those present at the TPS to exercise their right to vote are greater. Those who exercised their right to vote based on a combined total of $9.6 \%$ of voters who actively exercised their right to vote, plus $49.3 \%$ of voters who attended polling stations assisted by officers or organizers. The two present were added to $58.9 \%$ of disabled voters who were present at the polling stations on polling day.

In contrast to voters who did not exercise their right to vote, the absence rate was $41.1 \%$. This indicates that there are still many disabled voters who are not present to exercise their right to vote. The percentage figure is below those who attend and participate, but the number is still quite large.

The participation of voters with disabilities occurs because they have been advised by election management officers who are at the polling station (TPS) to attend TPS and use their voting rights properly, this is as stated by one of the informants, TPS officers called KPPS officers try their best to All voters can attend TPS and exercise their right to vote. This is an extension of the election organizers at the district level, either the General Election Commission (KPU) at the district level, or the Election Supervisory Body (Bawaslu).

Voters with disabilities try not to abstain (white people), this was conveyed by the informant. Although voting is a right, not an obligation, they cannot vote nor can they be blamed in the text of the election regulations, but it feels like something is lacking in social life when someone does not attend the invitation to vote at the polling station. They vote not every day, so that awareness is present to exercise their right to vote, for those who are aware of the importance of participating in using political rights. 
Throwing away the opportunity to vote is something to be avoided, according to the informant, for those who are aware of the substance of voting at the polling station booth. Disability voters who attended did not want to lose the opportunity to give their choice to the leaders who were contesting, among the candidates it was certain that they would

The existence of a candidate becomes an attraction for voters, because it becomes a hope that can answer the needs of disabled groups. Optimism of disability groups towards the future of the region is present at the Pilkada stage. This is illustrated during the campaign when the candidate pair for regional head was greeted

This information is analyzed using rational theory. Namely placing disabled voters who have rationalization of their rights and obligations as citizens. At first glance, rational theory places advantages or disadvantages in information on voter participation with disabilities in the 2020 elections.

Public perception of disabled voters in the use of their right to vote as illustrated in the explanation above shows that their understanding is diverse. With this research, it is hoped that the community will be closer to voters with disabilities, so that they feel that they are individualized, become part of society in general in the use of political rights in democratic parties.

\section{CONCLUSION}

Voters with disabilities actively participate in elections during the COVID-19 pandemic. The participation rate in the use of their voting rights is higher than in the previous election in a normal atmosphere. People's understanding of their participation is less thorough because the number of participants is getting higher. Hopefully it will be a concern for future policy makers in managing voters, especially voters with disabilities.

\section{REFERENCES}

[1] A. Mais and L. A. Yaum, "Aksesibiltas dan Partisipasi Politik Penyandang Disabilitas di Kabupaten Jember," KagangaJurnal Pendidik. Sej. Dan Ris. Sos.-Hum., vol. 2, no. 2, pp. 78-87, Dec. 2019, doi: 10.31539/kaganga.v2i2.830.

[2] A. Salabi, "Rata-Rata Partisipasi Pemilih Disabilitas di Pilkada 2020 64,62 Persen," Rumah Pemilu.org,
12, 2021. [Online]

Available: https://rumahpemilu.org/pemilihdisabilitas/

[3] H. Andriani and F. Amsari, "Hak Pilih Kelompok Penyandang Disabilitas Dalam Pemilihan Umum Tahun 2019 Di Sumatera Barat," J. Konstitusi, vol. 17, no. 4, p. 777, Jan. 2021, doi: 10.31078/jk1744.

[4] M. Kartika, "Pendataan Pemilih Disabilitas untuk Pilkada 2020 Disorot," Republika, Mar. 06 , 2020.

[Online].

Available:

https://www.republika.co.id/berita/q6qe2w 428/pendata an-pemilih-disabilitas-untukpilkada-2020-disorot

[5] P. Ananda, "KPU Fasilitasi Pendamping Bagi Pemilih Disabilitas," Media Indonesia, Nov. 20, 2020. [Online]. Available: https://mediaindonesia.com/politik-danhukum/362605/kpu-fasilitasi-pendampingbagi- pemilih-disabilitas

[6] "Political Participation of Disability Communities in Makassar Mayor Election 2018.pdf.'

[7] S. Reher, "How Do Voters Perceive Disabled Candidates?," Front. Polit. Sci., vol. 2, p. 634432, Jan. 2021, doi: 10.3389/fpos.2020.634432.

[8] T. Y. Rahmanto, "Hak Pilih Bagi Penyandang Disabilitas Mental Ditinjau dari Perspektif Hak Asasi Manusia," J. HAM, vol. 10, no. 1, p. 19, Jul. 2019, doi: 10.30641/ham.2019.10.19-37.

[9] J. W. Dwintari, “AKSESIBILITAS PENYANDANG DISABILITAS DALAM PEMILIHAN UMUM DI INDONESIA," no. 2, p. 30, 2018.

[10] "Aksesibilitas Penyandang Disabilitas dalam Pemilu 2019 di Kabupaten Sleman.pdf."

[11] R. Vebrianto, M. Thahir, Z. Putriani, I. Mahartika, A. Ilhami, and D. Diniya, "Mixed Methods Research: Trends and Issues in Research Methodology," J. Educ. Learn., vol. 1 , no. 2 , p. 11,2020

[12] N. F. Tungka, "COMBINING QUALITATIVE AND QUANTITATIVE METHODS IN DATA ANALYSIS," vol. 2, no. 1, p. 4, 2016.

[13] N. L. Damayanti and M. A. Hidayat, "Hiperreality Of Social Media: A Phenomenology Study of Self Confession of Housewives of Facebook Users," J. Soc. Media, vol. 3, no. 2, p. 261, Oct. 2019, doi: 10.26740/jsm.v3n2.p261-277.

[14] R. Paternoster, C. M. Jaynes, and T. Wilson, "Rational Choice Theory and Interest in the 
'Fortune of Others,",

[15] J. Res. Crime Delinquency, vol. 54, no. 6, pp. 847-868, Nov. 2017, doi: $10.1177 / 0022427817707240$.

[16] "Modul Ringkas Pemilu Akses Bagi Penyandang Disabilitas MODUL RINGKAS PEMILU AKSES BAGI PENYANDANG DISABILITAS.pdf."

[17] "PEMENUHAN HAK MEMILIH BAGI PENYANDANG DISABILITAS DALAM PEMILU TAHUN 2019 (STUDI DI KABUPATEN MALANG).docx."

[18] S. N. Lestari, "Pilkada 2020: Cara Pencoblosan bagi Disabilitas Netra, Rungu, Daksa," Tirto.Id, Desember 2020. [Online]. Available: https://tirto.id/pilkada-2020cara-pencoblosan-bagi-disabilitas-netrarungu-daksa- $\mathrm{f} 7 \mathrm{Sj}$

[19] A. M. Fauzi, M. Mudzakir, and M. O. Abdulrahim, "Social Conflict In Contestation Of Indonesia Election," J. Soc. Media, vol. 3, no. 2, p. 159, Oct. 2019, doi: 10.26740/jsm.v3n2.p159-177.

[20] A. A. Sahid and Mohd. S. Bin Shahruddin, "Political Rights of the Citizen in the 2014 Election and the Democracy Index in West Java: The Importance to Strengthen the Accessibilities," Polit. Indones. Indones. Polit. Sci. Rev., vol. 3, no. 2, pp. 173-195, Jul. 2018, doi: 10.15294/ipsr.v3i2.13697.

[21] M. Ramadhani, "Perlindungan Hukum Hak Memilih Penyandang Disabilitas Dalam Pemilihan Umum," Jurist-Diction, vol. 3, no. 1 , p. 243, Jan. 2020, doi: 10.20473/jd.v3i1.17635.

[22] H. A. Nasution and M. Marwandianto, "Memilih dan Dipilih, Hak Politik Penyandang Disabilitas dalam Kontestasi Pemilihan Umum: Studi Daerah Istimewa Yogyakarta,” J. HAM, vol. 10, no. 2, p. 161, Nov. 2019, doi: 10.30641/ham.2019.10.161178 .

[23] M. Syahbandir and L. Oktarina, "The Analysis of the Participation of People with Disabilities in the 2017's Regional Election in Bireuen District, Aceh, Indonesia," vol. 13, p. 14, 2020. 